\title{
House Dust Mites in Erzincan Province
}

\author{
Erzincan İl’inde Görülen Ev Tozu Akarları
}

\section{Erhan Zeytun', Salih Doğan', Medeni Aykut² ${ }^{1}$ Fatih Özçiçek ${ }^{3}$,Edhem Ünver ${ }^{4}$, Adalet Özçiçek}

1Department of Biology, Erzincan University Faculty of Arts and Sciences, Erzincan, Turkey

2Department of Biology, Dicle University Application and Research Center Science and Technology, Diyarbakır, Turkey

${ }^{3}$ Department of Internal Medicine, Erzincan University Faculty of Medicine, Erzincan, Turkey

${ }^{4}$ Department of Chest Diseases, Erzincan University Faculty of Medicine, Erzincan, Turkey

\section{ABSTRACT}

Objective: We aimed to determine the species of the house dust mites seen in Erzincan, the number of mites per gram of dust in the houses, and the relationship between temperature and the number of mite specimens.

Methods: For this purpose, 54 dust samples collected from 18 houses located in different districts of Erzincan province between November 2013 and January 2014. These samples were examined by a lactic acid precipitation method.

Results: Of the houses in which the dust samples were collected, $94.44 \%$ were found to be positive in terms of mites. A total of 844 mite specimens were isolated from the dust samples, and the mean number of mites per gram of dust was found to be 18.34 . The most common species was found to be Acarus siro (55.55\%) and was followed by Dermatophagoides pteronyssinus (50.00\%), Tyrophagus putrescentiae (22.22\%), Histiostoma sp. (22.22\%), Lepidoglyphus destructor (16.66\%), T. perniciosus (11.11\%), Euroglyphus maynei (11.11\%), Glycyphagus privatus (11.11\%), Cheyletus sp. (11.11\%), Tarsonemus sp. (11.11\%), and Tetranychus sp. (11.11\%).

Conclusion: Mite-holding rate of the houses in Erzincan province was found to be $94.44 \%$. The mean number of mites per gram of dust was found to be 18.34. The most common mite species was $A$. siro, which was followed by $D$. pteronyssinus.

(Turkiye Parazitol Derg 2015; 39: 124-30)

Keywords: House dust mite, allergy, temperature, Erzincan

Received: 02.07.2014

Accepted: 11.02.2015

\section{ÖZET}

Amaç: Bu çalışma Erzincan'da görülen ev tozu akar türlerini belirlemek, $1 \mathrm{~g}$ tozda bulunan akar sayısını tespit etmek ve ortam sıcaklığı ile akar sayısı arasındaki ilişkiyi araştırmak amacı ile yapılmıştır.

Yöntemler: Bu amaçla Erzincan ilinin farklı mahallelerinde bulunan 18 evden Kasım 2013 ile Ocak 2014 tarihleri arasında 3 ay süresince 54 toz örneği toplanmış ve laktik asitte çöktürme yöntemi ile incelenmiştir.

Bulgular: Toz örneği alınan evlerin \%94,44'ü akar bakımından pozitif bulunmuştur. Toz örneklerinden toplamda 844 akar örneği izole edilmiş, gram toz başına düşen ortalama akar sayısı 18,34 olarak belirlenmiştir. Evlerde en sık rastlanan tür Acarus siro $(\% 55,55)$ olmuş, bunu sıra-

This study was presented in the 22nd Biology National Congress, 23-27 June 2014, Eskişehir, Turkey.

Bu çalışma, 22. Ulusal Biyoloji Kongresi'nde sunulmuştur, 23-27 Haziran 2014 Eskişehir, Türkiye.

Address for Correspondence / Yazışma Adresi: Dr. Erhan Zeytun, Department of Biology, Erzincan University Faculty of Arts and Sciences, Erzincan, Turkey. Phone: +90 5426418632 E-mail: ezeytun@erzincan.edu.tr

DOI: $10.5152 /$ tpd.2015.3759

CTelif hakkı 2015 Türkiye Parazitoloji Derneği - Makale metnine www.tparazitolderg.org web sayfasından ulaşılabilir.

CCopyright 2015 Turkish Society for Parasitology - Available online at www.tparazitolderg.org 
sı ile Dermatophagoides pteronyssinus (\%50,00), Tyrophagus putrescentiae (\%22,22), Histiostoma sp. (\%22,22), Lepidoglyphus destructor $(\% 16,66)$, T. perniciosus $(\% 11,11)$, Euroglyphus maynei $(\% 11,11)$, Glycyphagus privatus $(\% 11,11)$, Cheyletus sp. $(\% 11,11)$, Tarsonemus sp. $(\% 11,11)$ ve Tetranychus sp. $(\% 11,11)$ izlemiştir.

Sonuç: Erzincan'da evlerin akar bulundurma oranı \%94,44 olarak belirlenmiştir. Gram toz başın düşen ortalama akar sayısı 18,34 olarak bulunmuştur. Evlerde en sık rastlanan türün Acarus siro olduğu ve bunu Dermatophagoides pteroyssinus'un takip ettiği görülmüştür. (Turkiye Parazitol Derg 2015; 39: 124-30)

Anahtar Sözcükler: Ev tozu akarı, alerji, sıcaklık, Erzincan

Geliş Tarihi: 02.07.2014

Kabul Tarihi: 11.02.2015

\section{INTRODUCTION}

House dust mites belonging to the subclass Acari are members of arachnid organisms. They difficult to see with the naked eye as their body size is approximately $100-400 \mu \mathrm{m}$. In houses, they are found in carpets and fabric-covered furniture, in particular, in living rooms and in beds, pillows, sheets, comforters, and carpets close to the bed in bedrooms. Their basic food sources are protein- and lipid-rich human skin rashes. In general, the term "house dust mites" is used to describe the mite species of Dermatophagoides pteronyssinus, D. farinae, and Euroglyphus maynei, which belong to the family Pyroglyphidae and continuously live in house dust. These mites transform from the egg stage to the adult stage within 3 to 4 weeks under humid conditions at temperature of $25-30^{\circ} \mathrm{C}$. The average lifetime of adult mites is $4-6$ weeks, and every female mite produces approximately 40-80 eggs during this time, which helps maintain this population (1).

Today, many commonly seen allergic diseases, including allergic asthma, allergic rhinitis, allergic conjunctivitis, and eczema, are caused by allergens. The most common allergens are house dust mites, which are too small to be visible. The impact of these mites as allergens results from their stools of 20-50 $\mu \mathrm{m}$, which are digestive tract residues. Colloff (1) cited from a study by Tovey et al. (2) that mites defecate a mean of 20 times a day. These stools containing various chemicals belonging to mites remain suspended in air for a while depending on several activities in houses and are then taken into the body by inhalation. As a result, these stools stimulate the immune system in atopic (prone to allergy) individuals, initiating allergic reactions (1).

Approximately, 1-2\% (65-130 million people) of the world population have house dust allergens (1). According to data from the World Health Organization, 235 million people in total are asthmatics, with children being the most commonly affected, followed by adults. More than $80 \%$ of deaths from asthma occur in low-and middle-income countries (3). These diseases may affect physical and psychosocial as well as school life and workforce of the patients. Similar to all over the world, house dust mites are a crucial problem in our country because of their impact both on the health and economy (4).

The determination of mite species in a residential area is very important for the elimination of allergic reactions seen in the area. On the contrary, although some studies have been conducted in our country on house dust mites, these are not sufficient. No previous study has been conducted in Erzincan province, which was selected as our study center, supporting this opinion. The objective of this study was to define the house dust mites seen in Erzincan province.

\section{METHODS}

The study was conducted in Erzincan province between November 2013 and January 2014. The study protocol was approved by the Chairman Ethics Committee of Erzincan University. Written informed consent was obtained from all participants whose homes included in the study. Within the scope of the study, a total of 54 dust samples was collected from 18 houses located at different sites in the city, once a month for three months. Indoor and outdoor temperatures of the houses and temperature of the surface from which the dust samples were collected were measured using an infrared thermometer (Trotec; Grebbener Strasse, Germany). The dust samples were collected from carpets and fabric-covered furniture in living rooms and from beds, pillows, sheets, comforters, and carpets close to the bed in bedrooms using a 1200 W vacuum cleaner (Bosch; München, Germany) applied on an area of $1 \mathrm{~m}^{2}$ for 2 min. To prevent mixing of house dusts with each other, disposable dust bags were used. In addition, subtracting hoses and mouthpieces of the vacuum cleaners were removed and cleaned in each house to prevent any possible contamination. The dust samples collected from the houses were put into locked plastic bags with the dust bags, labeled, and brought to the laboratory as soon as possible (maximum in $12 \mathrm{~h}$ ). The samples were then taken from the bags and were sifted through dry sieves having 1 and $0.5 \mathrm{~cm}$ pores, which were inserted under each other with a distance of $5 \mathrm{~cm}$ between them for separating coarse particles. After the dry sieving process, the samples were weighed using an assay balance to define the number of mites per gram and were studied through Spieksma-Bozeman's modified lactic acid precipitation method (5).

In the lactic acid precipitation method, $1 \mathrm{~g}$ of dust sample was put into a Petri dish; $90 \%$ lactic acid was poured on it, and the Petri dish was mixed with manual rotating movements to obtain a homogeneous mixture. The petri dishes were put on a hot plate heated up to $70-80^{\circ} \mathrm{C}$. After waiting for $1 \mathrm{~h}$ to separate small dust particles in it and to make it clearer, the dishes were removed from the plates and were left for cooling (1).

The complete area of the Petri dishes was examined under a stereo microscope (Leica Microsystems; Heerbrugg, Switzerland), and the visible mites were collected with the help of a finetipped needle. Mites obtained from the dust samples were collected and put into small Petri dishes containing $90 \%$ lactic acid and were kept for a day to be cleansed and cleared. After ensuring that the mites in the dishes were cleansed and whitened, indissoluble preparations were prepared in Hoyer's medium (20 $\mathrm{mL}$ glycerine, $30 \mathrm{~g}$ crystalline Arabic gum, $50 \mathrm{~mL}$ pure water, and $200 \mathrm{~g}$ chloral hydrate) (6). The mites were identified under a phase-contrast light microscope (Leica Microsystems; Heerbrugg, Switzerland) in accordance to relevant literature (1, 6-12). 
The dust samples and the houses from which the dust sample were collected were considered to be positive in terms of mites in case of the existence of larva, nymphs, or adult individuals. The mean number of mites per gram of dust was calculated by dividing the total mites collected from the mite $(+)$ samples to the number of mite $(+)$ samples.

Statistical analysis of the data obtained was performed using the Statistical Package for Social Sciences for Windows version 19.0 (SPSS, Chicago, IL, USA) software.

\section{RESULTS}

During the study period, 46 of the 54 (85.18\%) dust samples collected from 17 of the 18 (94.44\%) houses from which the samples were obtained were found to be mite-positive. Of the 46 mite-positive samples, a total of 844 mites were isolated. A minimum of 2 and maximum of 250 mites were found in the dust samples that weighed $1 \mathrm{~g}$, and the mean number of mites was found to be 18.34 per gram (Table 1).

In this study, a total 844 mite specimens were isolated with 692 from the order Astigmata, 78 from Prostigmata, 70 from Mesostigmata, and 4 from Cryptostigmata. The identification of the isolated mites belonging to Astigmata was performed at the species level, and a total of seven species belonging to the family were detected. Acarus siro from the family Acaridae was the most commonly seen mite in the houses (55.55\%) followed by $D$. pteronyssinus (50.00\%), Tyrophagus putrescentiae $(22.22 \%)$, Histiostoma sp. (22.22\%), Lepidoglyphus destructor (16.66\%), T. perniciosus (11.11\%), Euroglyphus maynei $(11.11 \%)$, and Glycyphagus privatus (11.11\%) (Figures 1-7). Mites belonging to the order Prostigmata were identified at the genus level, and in total, three genera from three families (Cheyletus sp., Tarsonemus sp., and Tetranychus sp.) were detected, while the identification of the mites belonging to Mesostigmata and Cryptostigmata remained at the order level (Table 2).

During the course of dust collection from the houses, the surface temperature was found to be a minimum of $16^{\circ} \mathrm{C}$, a maximum of $23.5^{\circ} \mathrm{C}$, and an average of $18^{\circ} \mathrm{C}$ as recorded by the infrared thermometer. The minimum indoor temperature was found to be $19^{\circ} \mathrm{C}$; the maximum was $24.9^{\circ} \mathrm{C}$ and the average was $21.2^{\circ} \mathrm{C}$. In addition, the outdoor temperature was found to be a minimum of $-13.6^{\circ} \mathrm{C}$, a maximum of $20.7^{\circ} \mathrm{C}$, and an average $3.9^{\circ} \mathrm{C}$ (Table 3).

These temperatures and the number of mite specimens isolated from the house dust samples were analyzed by Spearman's cor- relation test. A significant positive correlation was found in our study among the indoor temperature of the house, temperature of the surface, and number of mite specimens. No significant

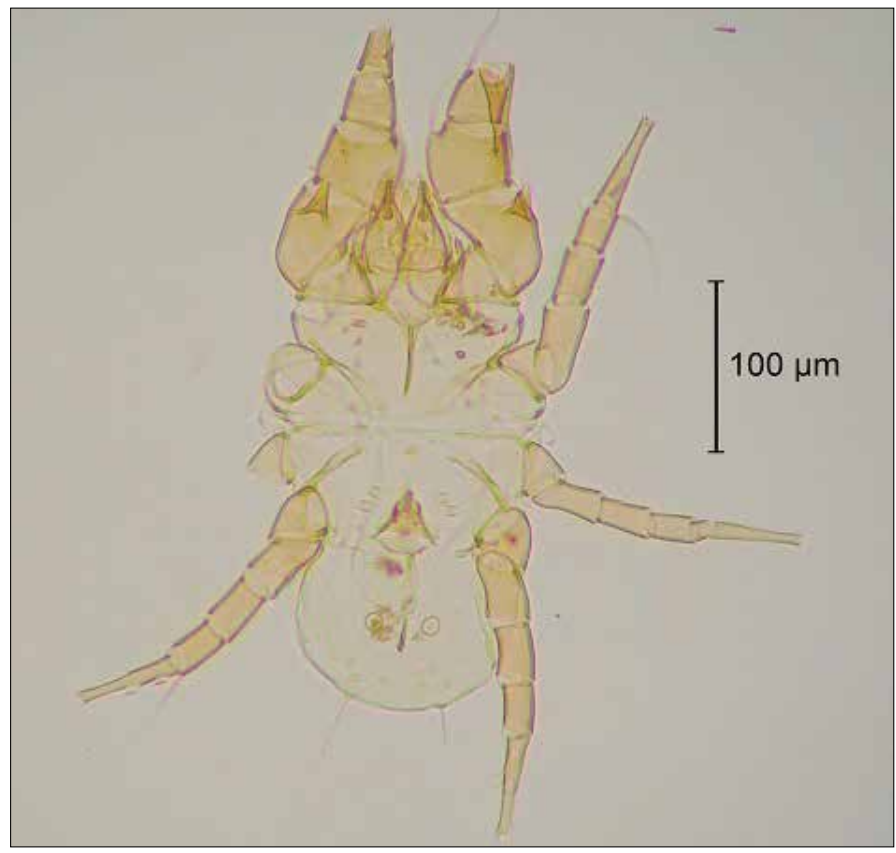

Figure 1. Acarus siro (male)

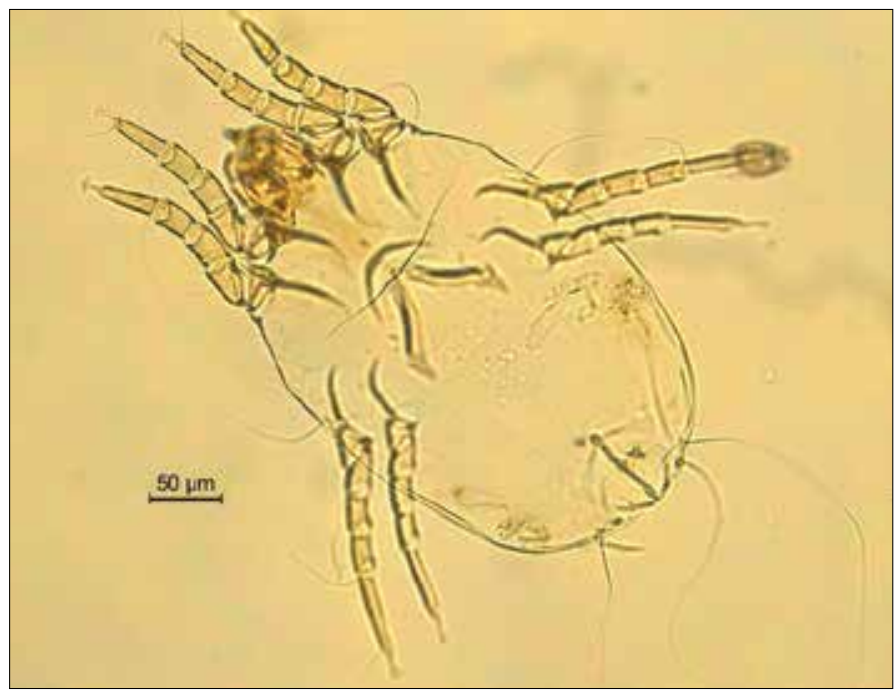

Figure 2. Dermatophagoides pteronyssinus (female)

Table 1. The incidence of house dust mites in Erzincan province and number of mites in $1 \mathrm{~g}$ of dust

\begin{tabular}{|c|c|c|c|c|c|c|c|c|}
\hline & \multicolumn{2}{|c|}{$\begin{array}{c}\text { Number of } \\
\text { houses }\end{array}$} & \multicolumn{2}{|c|}{$\begin{array}{c}\text { Number of } \\
\text { collected } \\
\text { dust samples }\end{array}$} & \multirow[t]{2}{*}{$\begin{array}{c}\text { Number of } \\
\text { isolated } \\
\text { mites }\end{array}$} & \multicolumn{3}{|c|}{$\begin{array}{c}\text { Number of mites } \\
\text { in the dust samples that } \\
\text { weighed } 1 \mathrm{~g}\end{array}$} \\
\hline & $n$ & $\%$ & $n$ & $\%$ & & Minimum & Maximum & Average \\
\hline Mite (-) & 1 & 5.56 & 8 & 14.82 & - & - & - & - \\
\hline Total & 18 & 100 & 54 & 100 & 844 & 2 & 250 & 18.34 \\
\hline
\end{tabular}


Table 2. Incidence of house dust mites in Erzincan

\begin{tabular}{|l|c|c|c|}
\hline Mites & Number of houses (n:18) & Incidence in houses (\%) & Number of isolated mites \\
\hline Astigmata & 15 & 83.33 & 692 \\
\hline Acarus siro & 10 & 55.55 & 516 \\
\hline Dermatophagoides pteronyssinus & 9 & 50.00 & 44 \\
\hline Tyrophagus putrescentiae & 4 & 22.22 & 24 \\
\hline Histiostoma sp. & 4 & 22.22 & 10 \\
\hline Lepidoglyphus destructor & 3 & 16.66 & 36 \\
\hline Tyrophagus pernicious & 2 & 11.11 & 20 \\
\hline Euroglyphus maynei & 2 & 11.11 & 4 \\
\hline Glycyphagus privatus & 2 & 11.11 & 78 \\
\hline Prostigmata & 6 & 33.33 & 30 \\
\hline Cheyletus sp. & 2 & 11.11 & 20 \\
\hline Tarsonemus sp. & 2 & 11.11 & 28 \\
\hline Tetranychus sp. & 2 & 11.11 & 70 \\
\hline Mesostigmata & 4 & 22.22 & \\
\hline Cryptostigmata & 1 & 5.55 & \\
\hline Total & & & \\
\hline
\end{tabular}

Table 3. Temperature values measured during the research

\begin{tabular}{|l|c|c|c|}
\hline & $\begin{array}{c}\text { Temperature of the surface from } \\
\text { which the samples were collected }\left({ }^{\circ} \mathrm{C}\right)\end{array}$ & $\begin{array}{c}\text { Indoor } \\
\text { temperature }\left({ }^{\circ} \mathrm{C}\right)\end{array}$ & $\begin{array}{c}\text { Outdoor } \\
\text { temperature }\left({ }^{\circ} \mathrm{C}\right)\end{array}$ \\
\hline Minimum & 16 & 19 & -13.6 \\
\hline Maximum & 23.5 & 24.9 & 20.7 \\
\hline Average & 18 & 21.2 & 3.9 \\
\hline
\end{tabular}

Table 4. The relationship between temperature parameters and the number of mite specimens

\begin{tabular}{|l|c|c|}
\hline Temperature parameters & $\mathbf{r}_{\mathbf{s}}$ & $\mathbf{p}^{*}$ \\
\hline Surface temperature $\left({ }^{\circ} \mathrm{C}\right)$ & 0.662 & $<0.001$ \\
\hline Indoor temperature $\left({ }^{\circ} \mathrm{C}\right)$ & 0.521 & $<0.001$ \\
\hline Outdoor temperature $\left({ }^{\circ} \mathrm{C}\right)$ & 0.252 & 0.091 \\
\hline *Spearman's correlation test, $\mathrm{r}_{\mathrm{s}}$ : correlation coefficient \\
\hline
\end{tabular}

relationship was found between the outdoor temperature and the number of mite specimens (Table 4).

\section{DISCUSSION}

During the study period, 46 of the 54 (85.18\%) dust samples collected from 17 of the 18 (94.44\%) houses were found to be mite-positive, and a total of 844 mite specimens were isolated from the dust samples of $1 \mathrm{~g}$. Studies conducted in our country have reported the mite-holding rates of houses to be $18.6 \%$ across Turkey, $48.4 \%$ in the Mediterranean, and $46 \%$ in the Black Sea region (13); $86.8 \%$ in the Eastern Mediterranean (14); $24.06 \%$ in Anatolian cities (15); $28.65 \%$ in Ankara (16); $18 \%$ in Sivas (17); $20 \%$ in another study from Sivas in the houses of asthmatic patients (18); 30\% in Afyonkarahisar (19); 53.8\% in İzmir (20); $57.66 \%$ in Konya $(21) ; 18.05 \%$ in Kütahya $(22) ; 29.3 \%$ in another study from Kütahya (23); $34.38 \%$ in Bursa (24); $23.1 \%$ in Malatya

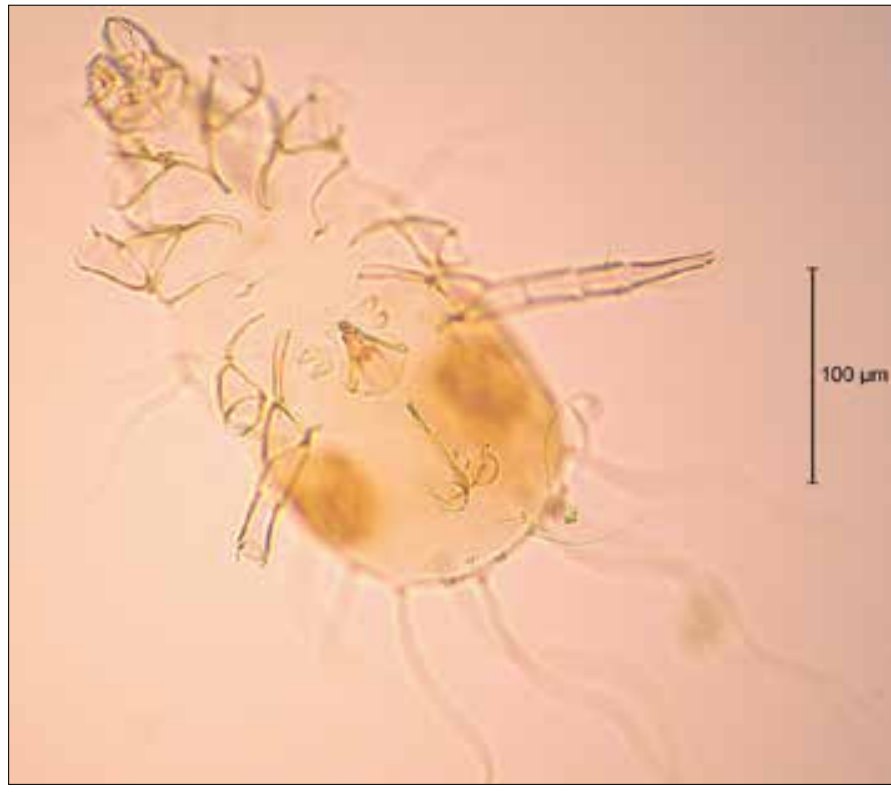

Figure 3. Tyrophagus putrescentiae (male)

(25); 22.72\% in Aydın (26); 23.6\% in Isparta, 24.2\% in Afyonkarahisar, $22.7 \%$ in Kütahya, $19.6 \%$ in Uşak, and 24\% in Denizli (27); $16.67 \%$ in Eskişehir (28); 48\% in Hasköy county of Muş (29); $39.47 \%$ in Kayseri (30); $20 \%$ in another study from Kayseri (31); and $72.21 \%$ 


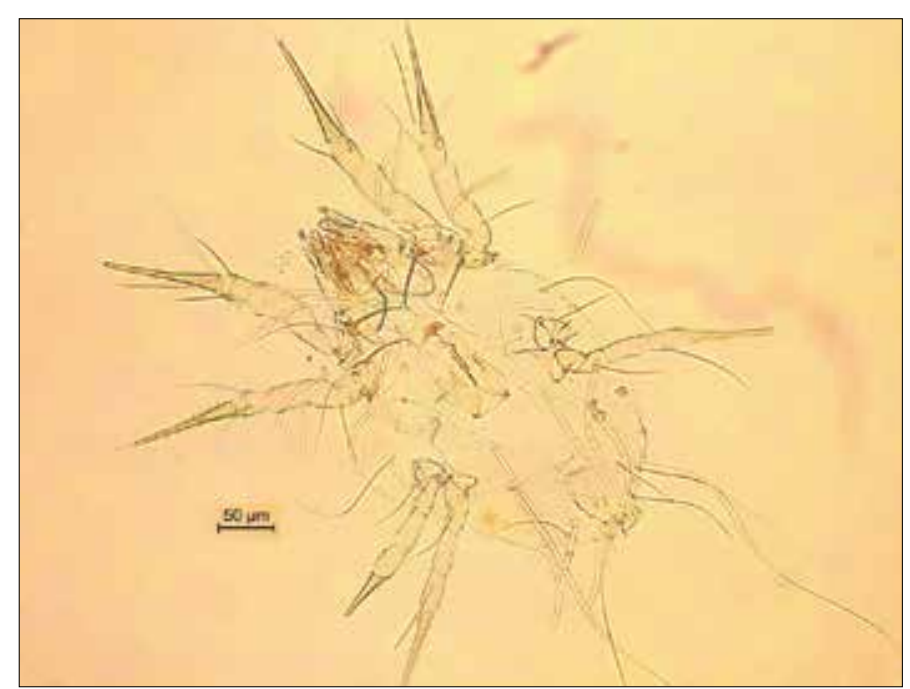

Figure 4. Lepidoglyphus destructor (female)

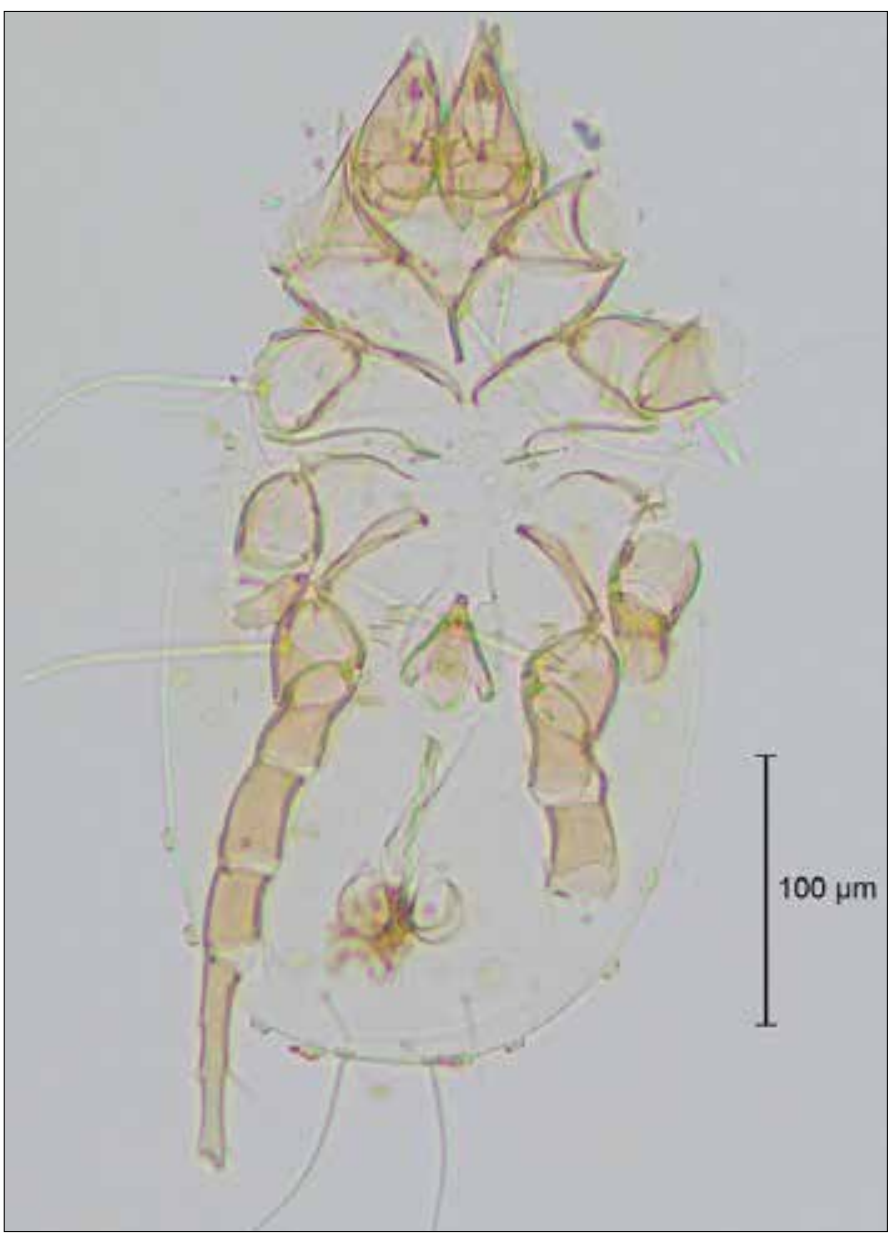

Figure 5. Tyrophagus perniciosus (male)

in Bitlis and Muş provinces (32). Studies conducted abroad have reported the mite-holding rate to be $85 \%$ during the autumn and $50 \%$ during the winter in Switzerland (33); $81.7 \%$ in eight different regions (Ohio, New Orleans, Memphis, Texas, Greenville, San Diego, Los Angeles, and California) in the USA where asthmatic patients lived (34); $51.3 \%$ in houses, $50 \%$ in

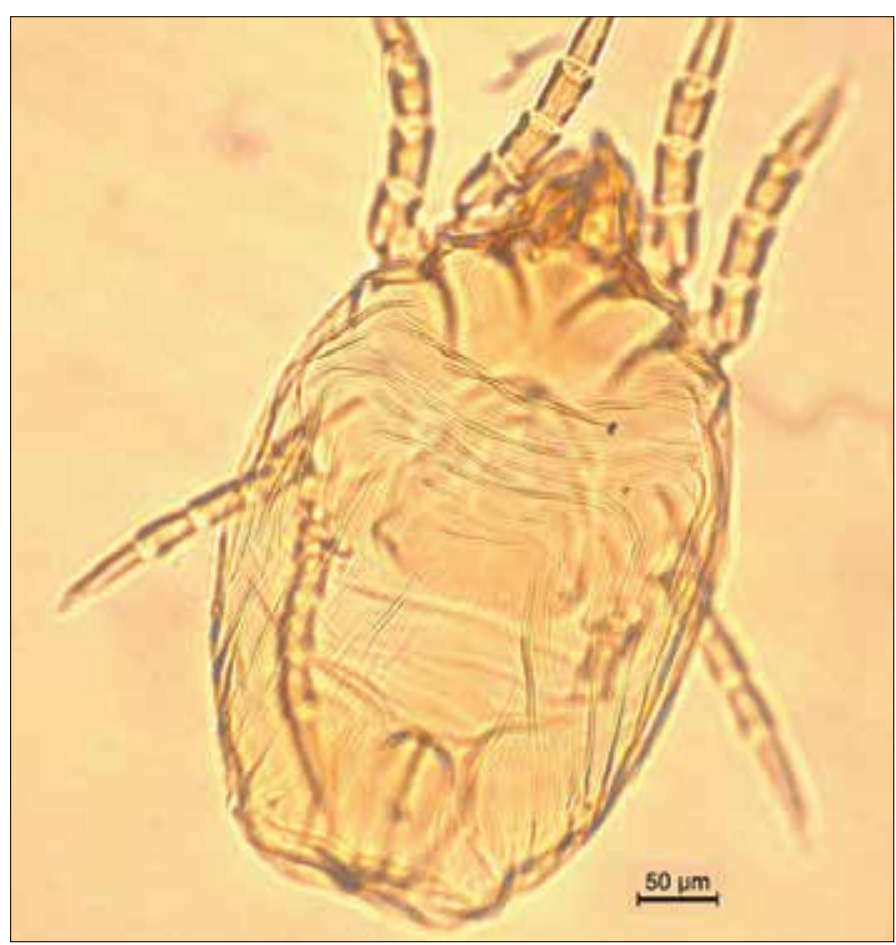

Figure 6. Euroglyphus maynei (female)

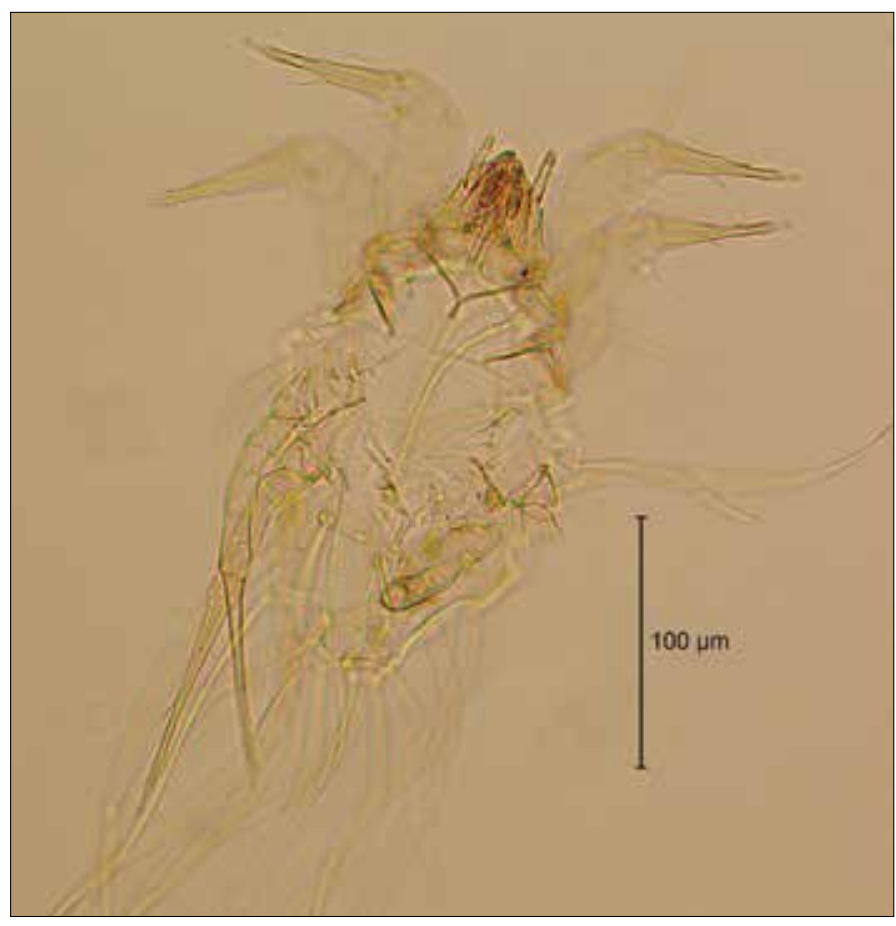

Figure 7. Glycyphagus privatus (male)

libraries, and $21.3 \%$ in hospitals located in Poland (35); $47.8 \%$ in south-west Poland (36); $87.8 \%$ in Rome (37); 73.7\% in Puerto Rico (38); and $88 \%$ in Bandar Abbas province of Iran (39). In our study, the mite-holding rate of the houses (94.44\%) was higher than those of the other studies conducted both in our country and abroad. This study showed that Erzincan province has suitable conditions for the growth and proliferation of house dust mites. 
Of the mites identified in this study, A. siro (55.55\%) was the most common species in the houses followed by $D$. pteronyssinus (50.00\%), T. putrescentiae (22.22\%), Histiostoma sp. (22.22\%), L. destructor (16.66\%), T. perniciosus (11.11\%), E. maynei (11.11\%), G. privatus (11.11\%), Cheyletus sp. (11.11\%), Tarsonemus sp. (11.11\%), and Tetranychus sp. (11.11\%) (Table 2). Mite species have been found in varying rates in numerous studies from our country and abroad (15, 16, 22, 24, 25, 27-29, 31, 32, 37, 40-43). Majority of the studies conducted in our country and abroad have reported that the most common mite specie is $D$. pteronyssinus (13-16, 19-21, 24, 25, 27-29, 32, 34, 41, 43-48). In our study, the most common species was found to be $A$. siro followed by $D$. pteronyssinus. This result suggested that $A$. siro, which is a storage mite, is transferred to the houses through stored foods and that the houses have suitable conditions for the proliferation of this mite species.

It has been reported in many studies conducted on house dust mites that temperature has an effect on the growth and proliferation of mites $(1,13,15,22,25,27-29,32,34,39,41,48,49)$. In our study, we concluded that temperature may differ between indoor and outdoor environments and that this might be resulted from structural status, age, floor coating, and ventilation frequency of the houses. Based on this information, indoor, outdoor, and surface temperatures were measured with an infrared thermometer. The number of mite specimens detected in the houses was compared with these temperatures and were statistically analyzed. A significant positive correlation was found in our study among the indoor temperature of the house, temperature of the surface, and the number of mite specimens. Accordingly, the number of mite specimens increased with an increase in the indoor or surface temperature. No significant relationship was found between the outdoor temperature and number of mites, but the number of mite specimens was found to decrease in case of decrease in outdoor temperatures.

\section{CONCLUSION}

The mite-holding rate of the houses in Erzincan province included in this study was found to be $94.44 \%$. The number of mites per gram of dust was found to be 18.34. The most common species was $A$. siro, which was followed by $D$. pteronyssinus. The number of mites was found to be statistically correlated with the indoor and surface temperatures.

It was thought that temperature and relative humidity, which are among the factors affecting the population dynamics of house dust mites, should be measured not only in the outdoor but also in the indoor environment. House dust mites were proposed to be associated with allergic diseases, but this must first be confirmed with skin tests, serological tests, and clinical examination. This study should be studied in the province across with more houses to be included.

Ethics Committee Approval: Ethics committee approval was received for this study from Erzincan University Chairman of the Ethics Committee (2014-02/6).

Informed Consent: The participants had read and signed the informed consent form.
Peer-review: Externally peer-reviewed.

Author Contributions: Concept - E.Z., S.D.; F.Ö., M.A., E.Ü., A.Ö.; Design - E.Z., S.D.; F.Ö.; Supervision - S.D.; Funding - E.Z.; Materials - E.Z.; Data Collection and/or Processing - E.Z.; Analysis and/or Interpretation - E.Z., S.D., F.Ö, M.A.; Literature Review - E.Z.; Writing - E.Z., F.Ö.; Critical Review - S.D., M.A., F.Ö., A.Ö.; Other - E.Z., S.D., F.Ö., M.A., E.Ü., A.Ö.

Conflict of Interest: No conflict of interest was declared by the authors.

Financial Disclosure: This study was supported by a Research Fund of the Erzincan University (EUBAP-FEN-A-300614-0107).

Acknowledgement: We would like to thank all the residents who opened their home to us.

Etik Komite Onayı: Bu çalışma için etik komite onayı Erzincan Üniversitesi Etik Kurul Başkanlığı'ndan alınmıştır (2014-02/6).

Hasta Onamı: Ev sakinleri bilgilendirilmiş olur formunu okumuş ve imzalamışlardır.

Hakem Değerlendirmesi: Dış Bağımsız.

Yazar Katkıları: Fikir - E.Z., S.D.; F.Ö., M.A., E.Ü., A.Ö.; Tasarım - E.Z., S.D.; F.Ö.; Denetleme - S.D.; Kaynaklar - E.Z.; Malzemeler - E.Z.; Veri toplanması ve/veya işlemesi - E.Z.; Analiz ve/veya yorum - E.Z., S.D., F.Ö, M.A.; Literatür taraması - E.Z.; Yazıyı yazan - E.Z., F.Ö.; Eleştirel İnceleme - S.D., M.A., F.Ö., A.Ö.; Diğer - E.Z., S.D., F.Ö., M.A., E.Ü., A.Ö.

Çıkar Çatışması: Yazarlar çıkar çatışması bildirmemişlerdir.

Finansal Destek: Bu çalışma Erzincan Üniversitesi Bilimsel Araştırma Projeleri Koordinatörlüğü tarafından desteklenmiştir (EUBAP- FEN-A300614-0107).

Teşekkür: Bize evlerini açan tüm ev sakinlerine teşekkür ederiz.

\section{REFERENCES}

1. Colloff MJ. Dust Mites. CSIRO Publishing, Collingwood, Australia; 2009. [CrossRef]

2. Tovey ER, Chapman MD, Wells CW, Platts-Mills TAE. The faeces are a major source of house dust mite allergens. Nature 1981; 289: 592-3. [CrossRef]

3. WHO. www.who.int/respiratory/asthma/en/ Erişim tarihi Mayıs 2014.

4. Gökçe S, Cevizci S, Kaypmaz A. Halk sağlığı penceresinden ev tozu akarları. TAF Prev Med Bulletin 2010; 9: 695-702.

5. Spieksma FT, Spieksma-Boezeman MIA. The mite fauna of house dust with particular reference to the house dust mite Dermatophagoides pteronyssinus (Trouessart, 1897) (Psoroptidae: Sarcoptiformes). Acarologia 1967; 9: 226-41.

6. Krantz GW, Walter DE. A Manual of Acarology. Third Edition. Texas Tech University Press, Lubbock, USA; 2009.

7. Hughes HM. The Mites of Stored Food and Houses. London Her Majesty's Stationery Office, London, UK; 1976.

8. Wolley TA. Mites and Human Welfare. A Willey-Interscience Publication; 1988.

9. Colloff MJ, Spieksma FT. Pictorial keys for the identification of domestic mites. Clin Exp Allergy 1992; 22: 823-30. [CrossRef]

10. Zhang Z-Q. Mites of Greenhouses Identification, Biology and Control. CABI Publishing, London, UK; 2003. [CrossRef]

11. Fan Q-H, Zhang Z-O. Tyrophagus (Acari: Astigmata: Acaridae). Fauna of New Zealand 2007; 56: 1-291.

12. Solarz K. House Dust Mites, Other Domestic Mites and Forensic Medicine. Medical University of Silesia in Katowice, Poland; 2012.

13. Kalpaklioglu AF, Emekci M, Ferizli AG, Mısırlıgil Z. A survey of acarofauna in Turkey: Comparison of seven different geographic regions. Allergy Asthma Proc 2004; 25: 185-90. 
14. Dönmez M. Doğu Akdeniz bölgesinde respiratuar allerjilerde ev tozu akarlarının rolü. Ankara: Ankara Üniversitesi Sağlık Bilimleri Enstitüsü. 1986

15. Kalpaklioglu AF, Emekci M, Ferizli AG, Mısırlıgil Z. House dust mite fauna in Turkey. J Investig Allergol Clin Immunol 1997; 7: 578-82.

16. Acıcan T. Türk ev tozu mite faunasının saptanması, antijen elde edilmesi ve antijen-hasta ilişkisinin kurulması. Adana: Çukurova Üniversitesi Tıp Fakültesi. 1992.

17. Aygan Ç, Özçelik S. Sivas yöresinde ev tozu akarlarının yaygıılığı ve atopik alerjideki rolü. Turkiye Parazitol Derg 2002; 26: 186-91.

18. Gönlügür Efeoğlu T. Sivas'ta 1285 metre yükseklikte yaşayan astımlı hastaların ev tozu akar duyarlııkları ve ev özelliklerinin etkisi. Sivas: Cumhuriyet Üniversitesi Tıp Fakültesi. 2005.

19. Çiftçi iH, Çetinkaya Z, Atambay M, Kıyıldı N, Aycan ÖM, Daldal N. House dust mite fauna in western Anatolia, Turkey. Korean J Parasitol 2006; 44: 259-64. [CrossRef]

20. Gülbahar O, Mete N, Kokuludağ A, Sin A, Sebik F. House dust mite allergens in Turkish homes. Eur J Allergy Clin Immunol 2004; 59: 231. [CrossRef]

21. Aldemir OS, Baykan M. Su hazneli ve toz torbalı elektrik süpürgeleri ile toplanan toz örneklerinde ev tozu akarlarının (D. pteronyssinus) araştırılması. Kafkas Üniv Vet Fak 2004; 10: 171-3.

22. Akdemir C, Güldal H. House dust mite in Kutahya, Turkey. Turkiye Parazitol Derg 2005; 29: 110-5.

23. Akdemir C, Yılmaz S. Sensitization to house dust mite and mite fauna in selected children's homes in Kütahya, Turkey. Turk J Pediatr 2009; 51: 232-7.

24. Güleğen E, Girişgin $O$, Kütükoğlu F, Girişgin AO, Coşkun ŞZ. Mite species found in house dust in houses in Bursa. Turkiye Parazitol Derg 2005; 29: 185-7.

25. Atambay M, Aycan MÖ, Daldal N. House dust mite fauna in Malatya. Turkiye Parazitol Derg 2006; 30: 205-8.

26. Ertabaklar H, Yaman S, Ertuğ S. Adnan Menderes Üniversitesi Tıp Fakültesi Hastanesi Parazitoloji Laboratuvarına gönderilen ev tozlarında akar sıklığının araştııılması. Turkiye Parazitol Derg 2006; 30: 29-31.

27. Çiftçi iH, Çetinkaya Z, Aktepe OC, Kıyıldı N, Aycan ÖM, Atambay M ve ark. Ev tozu alerjenleri ve spesifik IgE arasındaki ilişki. Med J Kocatepe 2004; 5: 29-32.

28. Doğan N, Aycan ÖM, Miman Ö, Atambay M, Daldal N. Eskişehir'de ev tozu akarı görülme durumu. Turkiye Parazitol Derg 2008; 32: 139-41.

29. Aykut M, Yılmaz H. Distribution of house dust mites in Hasköy town, Muş. Turkiye Parazitol Derg 2010; 34: 160-3. [CrossRef]

30. Hasgül K. Kayseri'de ev tozu akarlarının araştırılması. Kayseri: Erciyes Üniversitesi Sağlık Bilimleri Enstitüsü. 2011.

31. Kılınçarslan LE. Kayseri'de ev tozu akarlarının yayılışı. Ankara: Ankara Üniversitesi Sağlık Bilimleri Enstitüsü. 2012.

32. Aykut M, Erman ÖK, Doğan S. Seasonal changes of house dust mite population in Bitlis and Muş provinces of Turkey. Turkiye Parazitol Derg 2013; 37: 113-7. [CrossRef]
33. Mumcuoğlu Y. House dust mite in Switzerland. J. Med. Ent 1976; 13 361-73. [CrossRef]

34. Arlian LG, Bernstein D, Bernstein IL, Friedman S, Grant A, Lieberman $P$ et al. Prevalence of dust mites in the homes of people with asthma living in eight different geographic areas of the United States. J. Allergy Clin Immunol 1992; 90: 292-300. [CrossRef]

35. Solarz K. The allergenic acarofauna of house dust from dwellings, hospitals, libraries and institutes in upper Silesia (Poland). Ann Agric Environ Med 1998; 5: 73-85.

36. Solarz K. Indoor mites and forensic acarology. Exp Appl Acarol 2009; 49: 135-42. [CrossRef]

37. Bigliocchi F, Maroli D. Distribution and abundance of house dust mites (Acarina: Pyroglyphidae) in Rome, Italy. Int J Aerobiol 1995; 11: 35-40. [CrossRef]

38. Montealegre F, Sepulveda A, Boyama M, Quinones C, FernandezCaldas E. Identification of the domestic mite fauna of Puerto Rico. J Health Sci 1997; 16: 109-16.

39. Soltani A. The fauna and distribution of house dust mites in residential homes of Bandar Abbas District, Southern Iran. Exp Appl Acarol 2011; 54: 269-76. [CrossRef]

40. Sarıca A. Ankara ev toz akarları ve alerjik etkileri (Acarina: Acari). Ankara: Gazi Üniversitesi Fen Bilimleri Enstitüsü. 1997.

41. Aycan ÖM, Atambay M, Daldal N. Ev tozu akarlarının görülme durumunun sosyal değişkenler açısından incelenmesi. Turkiye Parazitol Derg 2007; 31: 219-24.

42. Çelik N. Samsun ilinde ev tozu akarı türlerinin belirlenmesi ve alerjik astım ile arasındaki ilişkinin ortaya konulması. Samsun: Ondokuzmayıs Üniversitesi Fen Bilimleri Enstitüsü. 2009.

43. Kosik-Bogacka DI, Kalisinska E, Henszel L, Kuzna-Grygiel W. Seasonal dynamics of house dust mites in dust samples collected from sleeping places in North-Western Poland. Zoonoses Public Health 2012; 59: 8-15. [CrossRef]

44. Colloff MJ. Distribution and abundance of dust mites within homes. Allergy 1998; 53: 24-7. [CrossRef]

45. Sporik R, Hill DJ, Thompson PJ, Stewart GA, Carlin JB, Nolan TM et al. The Melbourne house dust mite study: Long-term efficacy of house dust mite reduction strategies. J. Allergy Clin Immunol 1998; 101: 451-6. [CrossRef]

46. Mumcuoğlu Y, Gat Z, Horowitz T, Miller J, Bar-Tana R, Ben-Zvi A et al. Abundance of house dust mites in relation to climate in contrasting agricultural settlements in Israel. Med Vet Entomol 1999; 13: 252-8. [CrossRef]

47. Gülbahar O, Korkmaz, Erdem N, Gökmen NM, Sin AZ, Ardeniz Ö ve ark. An important source for cat and house dust mite allergens: daycare centers. Türkiye Klinikleri Med Sci 2012; 32: 750-8. [CrossRef]

48. Aykut M, Erman ÖK, Doğan S, Diyarbakır'da ev, otel ve öğrenci yurtlarında ev tozu akarlarının görülme durumu. Dicle Üniversitesi Fen Bilimleri Enstitüsü Dergisi 2013; 2: 41-7.

49. Colloff MJ. Age structure and dynamics of house dust mite populations. Exp Appl Acarol 1992; 16: 49-74. [CrossRef] 